\title{
Population Development in Finland during the 1960's
}

\author{
By MARKETTA RITAMIES
}

Population Research Institute

During recent years, the development of population in Finland has been the subject of relatively lively interest, even though the demographic occurrences in general have interested a comparatively small group of the people. As a rule, little more is done than establishing the number of inhabitants at the end of each year: otherwise, very little attention is directed to matters concerned with the population. Current interest is attributable to the change in direction apparent in the development of the number of inhabitants, which is expected to bring in its train many consequences which will primarily affect the future development of Finland in a negative way.

The development of population is dependent upon so many different factors that this study is confined to some of them concerned with population, such as nativity, mortality, the frequency of marriage, and the migration movement. The part played by these factors is examined in connection with the emergence of the present population situation, and its interrelationships.

\section{Population growth}

The nineteen sixties involve a turning point for the development of population in Finland. The population growth became slower, and by the end of the decade the population was diminishing. To some extent the situation in the thirties and forties, when the diminution in population aroused concern, and led to the belief that the population of Finland would never exceed four millions, was repeated. The Modeen forecast published in 1934 appears to be correct in respect of the diminution in population during the seventies, even though it had been unable to forecast the marked increase in fertility during the late forties, which raised the number of population to a degree such that we can be concerned that a population figure of five millions now appears unattainable.

During the 1960's, the population increased by 257000 persons. The largest rise appeared during the beginning of the decade. During the last 
few years of the decade, the population growth was weak, and even a reduction was noted in 1969. Admittedly, Table 1 still shows an increase in population by 5000 people, since at that time one was not in a position to appraise the extent of emigration to Sweden, which during the year in question amounted to 32000 persons, and which involved that in reality the population figure sank for the first time since the years of great want of the 1860 's.

T a ble 1. Population development during the 1960's.

\begin{tabular}{lcccccc} 
Year & \multicolumn{2}{c}{ Whole country } & \multicolumn{2}{c}{$\begin{array}{c}\text { Towns and } \\
\text { townships }\end{array}$} & \multicolumn{2}{c}{ Rural communes } \\
& In 1000 s & Per cent & In 1000 s & Per cent & In 1000s & Per cent \\
$1960 / 61$ & 4446 & 100.0 & 1707 & 38.4 & 2739 & 61.6 \\
$1961 / 62$ & 4487 & 100.0 & 1753 & 39.1 & 2734 & 60.9 \\
$1962 / 63$ & 4523 & 100.0 & 1799 & 39.8 & 2724 & 60.2 \\
$1963 / 64$ & 4562 & 100.0 & 1918 & 42.0 & 2644 & 58.0 \\
$1964 / 65$ & 4598 & 100.0 & 1986 & 43.2 & 2612 & 56.8 \\
$1965 / 66$ & 4626 & 100.0 & 2050 & 44.3 & 2578 & 55.7 \\
$1966 / 67$ & 4653 & 100.0 & 2124 & 45.6 & 2529 & 54.4 \\
$1967 / 68$ & 4679 & 100.0 & 2241 & 47.9 & 2438 & 52.1 \\
$1968 / 69$ & 4698 & 100.0 & 2294 & 48.8 & 2404 & 51.2 \\
$1969 / 70$ & 4703 & 100.0 & 2363 & 50.2 & 2340 & 49.8
\end{tabular}

Source: Bulletin of Statistics 1971, 2.

At the beginning of the 1960's, the population of the rural communes exceeded 60 per cent, but the migration that had started during the preceding decade continued, and people moved into the residential centres, and from primary production to industry and service work. At the end of the 1960 's, the situation arose that the urban population was for the first time greater in numbers than that of the rural areas. (Table 1).

Simultaneously with the increase in population in residential centres, the state of equilibrium between the populations in the various parts of the country diminished. The migration brought population from remote tracts in the eastern parts of the country to Southwest and South Finland, and in particular to Uusimaa. This is illustrated by the following table relating to the changes in percentage that were registered during the 1960's.

Percentage changes in number of population in administrative provinces

$\begin{array}{ll}\text { Uudenmaan lääni } & +22.1 \\ \text { Hämeen lääni } & +10.1 \\ \text { Lapin lääni } & +6.6 \\ \text { Turun-Porin lääni } & +3.4 \\ \text { Oulun lääni } & +3.1 \\ \text { Kymen lääni } & +3.1 \\ \text { Ahvenanmaa (Åland) } & +2.9\end{array}$

Keski-Suomen lääni $\quad+0.8$

Vaasan lääni $\quad-1.8$

Kuopion lääni $\quad-2.7$

Mikkelin lääni $\quad-4.8$

Pohj.Karjalan lääni $\quad-8.2$

Whole country $\quad+5.9$ 
The population of Finland did not change only in numbers, but also in a structural aspect. A certain increase occurred in the age structure (Table 2). The proportion of young people, those under 14 years of age, of the entire population diminished, while the proportions of age groups 15-64 years and retired people increased. During the years from 1960 to 1968 , the number of people on pension, that is the number who had reached the age of 65 , rose by 70000 : at the same time, the diminution in children under five years of age was 30000 (Salovaara 1970, 10-11).

The changes in the age structure between the residential centres and rural communities are shown in Diagram 1, which illustrates the age pyramids. The migration movement brought young people from the rural areas to the towns and townships. The age structure of a part of the population remaining became gradually older. The average age of the farming population has been established as a good ten years higher than that of the entire population engaged in professional work.

The sex structure of the population was evened out to some extent during the 1960's. The situation in rural areas was improved in particular, if the entire population is taken into account. The uneven distribution of the sexes, however, becomes apparent on examination by age classes. The woman-dominated migration movement in the younger age classes meant that the male dominance was maintained in the rural areas.

The surplus of women in towns and townships is noteworthy, especially in regard to the working age groups.

Table 2. Age structure of population during the 1960's, as percentages.

$\begin{array}{lcccc}\text { Year } & \begin{array}{c}\text { Children } \\ (0-14)\end{array} & \begin{array}{c}\text { Aged } \\ 15-64\end{array} & \begin{array}{c}\text { Retired } \\ (65-)\end{array} & \text { Totals } \\ 1960 & 30.1 & 62.4 & 7.4 & 100.0 \\ 1961 & 29.5 & 63.0 & 7.5 & 100.0 \\ 1962 & 28.7 & 63.8 & 7.5 & 100.0 \\ 1963 & 28.0 & 64.3 & 7.7 & 100.0 \\ 1964 & 27.4 & 64.7 & 7.9 & 100.0 \\ 1965 & 26.7 & 65.3 & 8.0 & 100.0 \\ 1966 & 26.3 & 65.5 & 8.2 & 100.0 \\ 1967 & 25.7 & 65.7 & 8.3 & 100.0 \\ 1968 & 25.7 & 66.1 & 8.3 & 100.0\end{array}$

Source: Statistical Yearbook of Finland 1970, p. 27.

\section{Fertility}

The frequency of births has declined evenly since the fifties. At the beginning of the 1960's, however, the frequency of births still averaged 18 per 1000 persons. Not until the final years of the decade did the 
Di a g r a m 1. Age pyramids of the population in towns, townships, rural communes, and in the entire country, years 1960 and 1968.
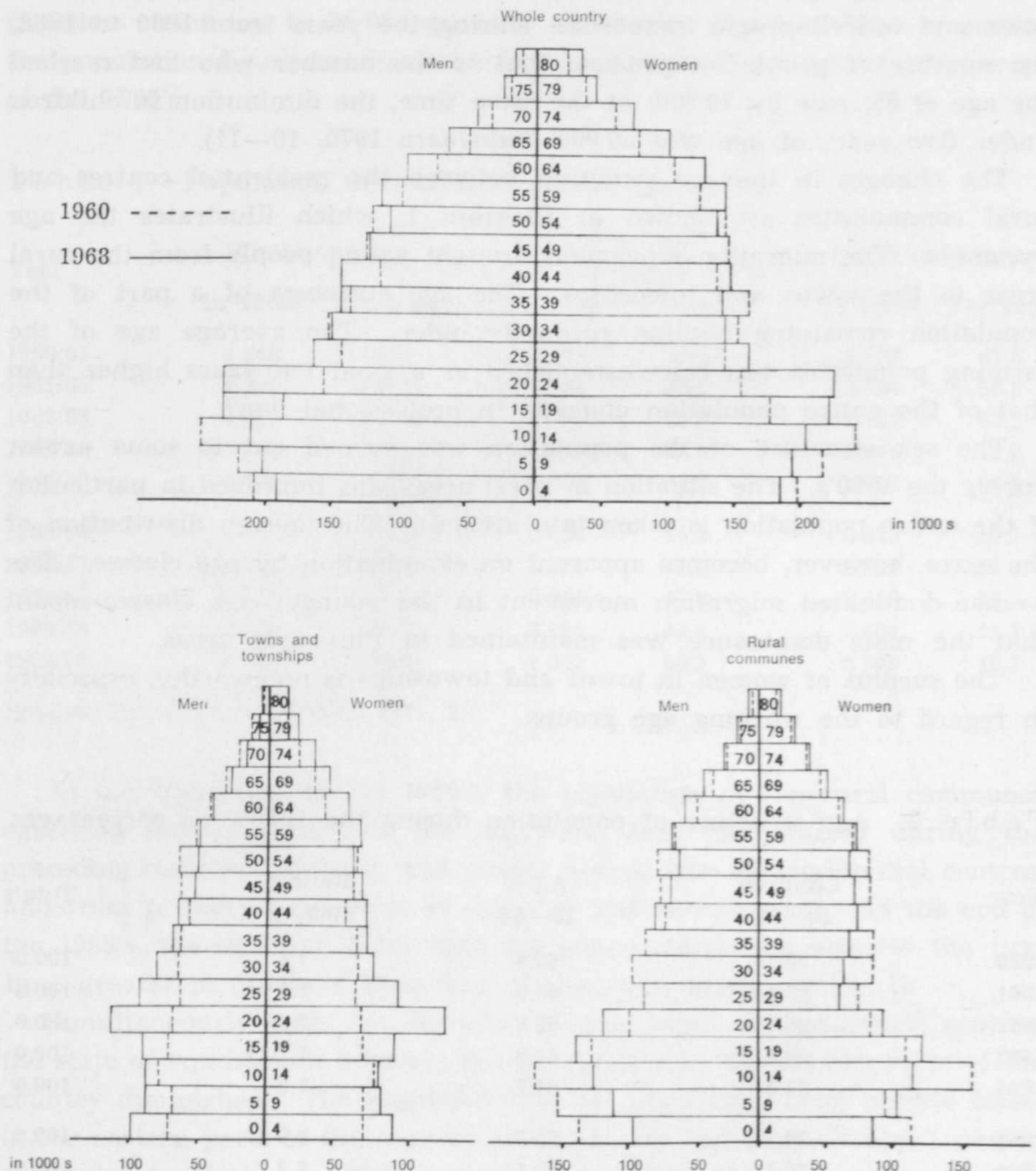

Sources: General Census of Population 1960, II. SVT VI C: 103, Helsinki 1963. Vital Statistics 1968, VI A: 130. Helsinki 1970. 
decline in birth frequency become more appreciable. During 1969, the number of live births per 1000 persons was 14 (Table 3).

Even by the beginning of the 1960's, the number of births in towns and townships was higher than that in rural areas. Nonetheless, the difference was still very small. As years went by, it became larger, and at the end of the decade amounted to 3.5 per 1000 . In the rural communes, the number of births declined steadily, but in towns and townships the number of births during the first four years of the decade rose, and not until subsequently did it begin to fall.

$\mathrm{Table} 3$. Live births per 1000 of the average number of population.

$\begin{array}{lcccc}\text { Year } & \text { Totals } & \begin{array}{r}\text { Whole country } \\ \text { Per } 1000\end{array} & \begin{array}{c}\text { Towns and } \\ \text { townships } \\ \text { Per } 1000\end{array} & \begin{array}{c}\text { Rural } \\ \text { communes } \\ \text { Per } 1000\end{array} \\ 1960 & 82129 & 18.5 & 18.6 & 18.3 \\ 1961 & 81996 & 18.4 & 18.7 & 18.0 \\ 1962 & 81454 & 18.1 & 19.1 & 17.4 \\ 1963 & 82251 & 18.1 & 19.5 & 17.1 \\ 1964 & 80428 & 17.6 & 19.3 & 15.2 \\ 1965 & 77885 & 16.9 & 18.7 & 15.1 \\ 1966 & 77697 & 16.7 & 18.8 & 14.8 \\ 1967 & 77289 & 16.5 & 18.5 & 12.9 \\ 1968 & 73654 & 16.0 & 17.5 & \\ 1969 & 67450 & 14.3 & 15.8 & \end{array}$

Sources: Bulletin of Statistics 1967, 1, and 1971, 5.

The decline in number of births was typical of all age classes. Only in the age classes under 20 did the number of births rise to some extent during the 1960's. During the closing years of the decade, however, a decline in the number of births could be established in this age class as well (Table 4).

$\mathrm{Table} 4$. Age-specific fertility rates per 1000 women during the years 1960-68.

$\begin{array}{lrrrrrrrrr}\text { Age } & 1960 & 1961 & 1962 & 1963 & 1964 & 1965 & 1966 & 1967 & 1968 \\ 15-19 & 28.4 & 27.8 & 27.8 & 30.3 & 31.6 & 33.7 & 35.1 & 35.5 & 35.0 \\ 20-24 & 162.9 & 159.4 & 161.4 & 159.2 & 152.7 & 139.0 & 138.1 & 135.1 & 129.2 \\ 25-29 & 158.7 & 159.3 & 156.4 & 157.0 & 149.9 & 143.1 & 136.7 & 132.7 & 120.1 \\ 30-34 & 103.9 & 102.4 & 100.1 & 100.5 & 95.0 & 90.4 & 88.5 & 81.5 & 75.0 \\ 35-39 & 61.3 & 61.1 & 55.9 & 55.4 & 53.2 & 51.9 & 47.4 & 45.3 & 38.5 \\ 40-44 & 25.0 & 25.4 & 23.4 & 22.6 & 22.2 & 19.2 & 17.0 & 16.2 & 14.1 \\ 45-49 & 2.4 & 2.4 & 2.2 & 2.3 & 2.0 & 2.3 & 1.8 & 1.7 & 1.5 \\ 15-49 & 75.7 & 75.9 & 74.3 & 73.8 & 71.1 & 67.9 & 67.0 & 65.6 & 63.2\end{array}$

Sources: Vital Statistics $1960-68$, SVT VI A: $119-130$. 
The net reproduction rate, which gives not only the proportions between the daughter and mother generations, but also takes account of mortality, provides the best picture of the decline in fertility, especially from the long-term aspect. The marked decline in fertility during the 1960 's becomes very evident from this, as is observable in the following table.

Net reproduction rate

$\begin{array}{llll}\text { Year } & & \text { Year } & \\ 1960 & 1.270 & 1965 & 1.135 \\ 1961 & 1.275 & 1966 & 1.105 \\ 1962 & 1.246 & 1967 & 1.058 \\ 1963 & 1.246 & 1968 & 0.981 \\ 1964 & 1.197 & 1969 & 0.867^{*}\end{array}$

It was only during some years of the 1930's, and the war years of the 1940 's, that such low reproduction rates as those registered in the last two years of the 1960's were attained.

\section{Mortality}

The continued decline in mortality that had been in progress for a long period came to an end during the sixties (Table 5). At the beginning of the decade, 9 persons per 1000 died, but by the end the corresponding figure was nearly 10 .

The rise in the age structure of the population had a heightening effect upon the mortality figures. As fertility had declined markedly, the proportion of the higher age classes in the population had grown in proportion. In the lower age classes, the probability of death still declined. This

$\mathrm{Table} 5$. Deaths per 1000 of the average number of population.

$\begin{array}{lccccc}\text { Year } & \begin{array}{c}\text { Whole country } \\ \text { Totals }\end{array} & \begin{array}{c}\text { Towns and } \\ \text { Per } 1000\end{array} & \begin{array}{c}\text { Rural } \\ \text { Per } 1000\end{array} & \begin{array}{c}\text { The infant mor- } \\ \text { communes } \\ \text { Per 1 000 }\end{array} & \begin{array}{c}\text { Per } 1000 \\ \text { Pelity rate }\end{array} \\ 1960 & 39797 & 9.0 & 8.5 & 9.2 & 21.0 \\ 1961 & 40616 & 9.1 & 8.8 & 9.3 & 20.8 \\ 1962 & 42889 & 9.5 & 8.9 & 9.9 & 20.5 \\ 1963 & 42010 & 9.2 & 8.6 & 9.7 & 18.2 \\ 1964 & 42512 & 9.3 & 8.6 & 9.8 & 17.0 \\ 1965 & 4473 & 9.6 & 8.8 & 10.3 & 17.6 \\ 1966 & 43548 & 9.4 & 8.6 & 10.0 & 15.0 \\ 1967 & 43790 & 9.4 & 8.6 & 10.1 & 14.8 \\ 1968 & 45013 & 9.6 & 8.7 & 10.5 & 14.4 \\ 1969 & 46017 & 9.8 & 8.9 & 10.7 & 13.9\end{array}$

Sources: Bulletin of Statistics 1964, 12, and 1970, 11.

Vital Statistics VI A: $119-130$. 
also applied to the infant mortality rate, which during the 1950's still fell within the order of magnitude of 25 per 1000 , fell appreciably during the 1960 's, and amounted to no more than barely 14 per 1000 in 1969 (Table 5). In the higher age classes, the probability of death grew, and in particular in rural areas mortality clearly rose by reason of the ageing of the population structure.

Finland's mortality rates are notably high in comparison with those of most European countries. In particular, male mortality in Finland is of the order of magnitude reached in no more than a few countries.

\section{Excess of births over deaths}

The excess of births over deaths, or the difference between births and deaths in relation to the average number of population, declined appreciably during the 1960's. During the early years of the decade, more than 40000 were born in excess of those who died, but by 1969 the figure had fallen to one half of this (Table 6).

T a ble 6. Excess of births over deaths during the 1960's.

\begin{tabular}{lcccc} 
Age & \multicolumn{2}{c}{$\begin{array}{c}\text { Thole country } \\
\text { Totals }\end{array}$} & $\begin{array}{c}\text { Per } 1000 \\
\text { townships } \\
\text { Per } 1000\end{array}$ & $\begin{array}{c}\text { Rural } \\
\text { communes } \\
\text { Per } 1000\end{array}$ \\
1960 & 42332 & 9.6 & 10.1 & 9.1 \\
1961 & 41380 & 9.3 & 10.1 & 8.7 \\
1962 & 38565 & 8.6 & 10.2 & 7.5 \\
1963 & 40241 & 8.9 & 10.9 & 7.4 \\
1964 & 37916 & 8.3 & 10.7 & 6.5 \\
1965 & 33412 & 7.2 & 9.8 & 5.2 \\
1966 & 34149 & 7.4 & 10.1 & 5.1 \\
1967 & 33499 & 7.2 & 9.9 & 4.7 \\
1968 & 28641 & 6.1 & 8.8 & 3.5 \\
1969 & $22069 *$ & $4.7 *$ & 6.9 & 2.2
\end{tabular}

Sources: Vital Statistics $1960-68$, SVT VI A: $119-130$.

The excess of births over deaths has declined mainly by reason of the decline in the number of births. In fact, mortality also to some extent increased during the 1960's, but the effect of this was less.

Although the natural increase in population of the rural communes was still during the 1950's greater than that in the towns and townships, the situation during the following decade was different. After the beginning of the 1960's, the excess of births over deaths in residential centres was nearly 50 per cent greater than that in the rural communes. 


\section{Nuptiality}

The sharp decline in fertility during the 1960's was in no way attributable to the marriage rates, as the large age classes born in 1946- 50 then reached the age of marriage, and accordingly raised the crude marriage rates. In 1960, 7.4 marriages per thousand inhabitants were solemnised, but the corresponding figure in 1969 was 8.7 (Table 7).

The numbers of marriages entered into rose during the 1960's in the towns, the townships and in rural areas. However, there were more marriages in the residential centres than in the rural areas, a consequence of the population being younger in structure.

The age for entering upon marriage further diminished. From the years after the second world war until $1960-64$, the age of marriage for

Table 7. Marriages entered into during the 1960's.

\begin{tabular}{|c|c|c|c|c|}
\hline Year & $\begin{array}{l}\text { Whole } \\
\text { Totals }\end{array}$ & $\begin{array}{l}\text { country } \\
\text { Per } 1000\end{array}$ & $\begin{array}{l}\text { Towns and } \\
\text { townships } \\
\text { Per } 1000\end{array}$ & $\begin{array}{c}\text { Rural } \\
\text { communes } \\
\text { Per } 1000\end{array}$ \\
\hline 1960 & 32834 & 7.4 & 9.5 & 6.1 \\
\hline 1961 & 34222 & 7.7 & 9.9 & 6.3 \\
\hline 1962 & 34251 & 7.6 & 9.8 & 6.2 \\
\hline 1963 & 33361 & 7.3 & 9.3 & 5.9 \\
\hline 1964 & 34520 & 7.5 & 9.5 & 6.1 \\
\hline 1965 & 36214 & 7.9 & 9.7 & 6.4 \\
\hline 1966 & 38252 & 8.2 & 10.2 & 6.6 \\
\hline 1967 & 41273 & 8.8 & 10.8 & 7.1 \\
\hline 1968 & 40251 & 8.6 & 10.2 & 7.1 \\
\hline 1969 & 40735 & 8.7 & & \\
\hline
\end{tabular}

Sources: Bulletin of Statistics 1964, 12 and 1970, 11.

Vital Statistics 1960-68 VI: A $119-130$.

Table 8. Marriage by age and sex during the years $1960-68$.

\begin{tabular}{lrrrr} 
Age & \multicolumn{2}{c}{ Women } & \multicolumn{2}{c}{ Men } \\
& 1960 & 1968 & 1960 & 1968 \\
$14-19$ & 20.9 & 24.8 & 6.0 & 7.5 \\
$20-24$ & 46.6 & 51.5 & 43.9 & 53.5 \\
$25-29$ & 16.1 & 12.7 & 26.6 & 22.2 \\
$30-34$ & 6.7 & 4.1 & 11.0 & 7.2 \\
$35-39$ & 3.6 & 2.3 & 4.5 & 3.4 \\
$40-44$ & 2.2 & 1.6 & 2.4 & 2.1 \\
$45-49$ & 1.8 & 1.1 & 1.9 & 1.2 \\
$50-$ & 2.1 & 1.9 & 3.7 & 2.9 \\
Totals & 100.0 & 100.0 & 100.0 & 100.0
\end{tabular}

Sources: Vital Statistics 1960-68, VI A: 119—130. 
girls fell from 24.7 to 21.5 , and for young men from 27.6 to 23.8 (Piepponen, 1968).

Most marriages were contracted between the ages of 20 to 24 , as is apparent from the Table 8 .

Men marry later than do women. Although the age at marriage of men declined, no more than about 8 per cent married under the age of 20 in 1968. The corresponding figure for women was 25 per cent.

\section{Migration}

Apart from the natural increase in population, development of the number of inhabitants is also dependent upon the frequency of migration. Migration affects the number of inhabitants of the different parts of the country, but emigration exercises an influence upon the population of the entire country. For a lengthy period, migration and emigration have not exerted any significant effect upon the development of the population: for the main part, this has been dependent upon the natural increase. Not until the last years of the 1960's did emigration become an important factor in changes in the population of the country.

\section{Internal migration}

The migration from rural areas to the densely populated parts of the country, a consequence of the social process of transformation, was in progress during the sixties. Nevertheless, the number of those who moved was evened out at some 205000 to 220000 people per annum. Comparison of the 1960's with earlier years is to some extent disturbed by the regional programme put into effect, which tended to raise the number of inhabitants. in towns and townships. The annual extent of migration is apparent from the following presentation.

\begin{tabular}{lrc} 
Year & \multicolumn{2}{c}{ Internal migrants } \\
& Number & Per 1000 \\
1960 & 221177 & 49.9 \\
1961 & 214919 & 48.1 \\
1962 & 214041 & 47.5 \\
1963 & 215137 & 47.4 \\
1964 & 219378 & 47.9 \\
1965 & 218320 & 47.3 \\
1966 & 212787 & 45.9 \\
1967 & 215596 & 46.2 \\
1968 & 204791 & 43.7 \\
1969 & 210580 & 44.8
\end{tabular}

In the streams of internal migration, two main directions are discernible, the removal from remote tracts to residential centres, and removal from 
the other parts of the country to south and south-western Finland, and in particular to Uusimaa. The communal balance of migration shows that towns and townships profit at the expense of rural areas. As an example of this, during the years $1961-65$, only 46 rural communes out of 476 had a net immigration balance, whereas 62 towns and townships out of 70 had a positive one. (Majava 1968, 51). The major part of the net immigration was assimilated by the country's southern parts, and in particular Uusimaa. During the years $1961-65$, the net immigration of Uusimaa was 92 per cent of the net immigration of all the statistical regions. The greatest losses that occurred as a result of population migration were experienced by North Carelia, Savo, Kainuu and Keski-Pohjanmaa statistical regions. All the rural communes of Pohjois-Karjala and Etelä-Savo belong to the 401 rural communes which without interruption experienced a negative migration balance after the beginning of the 1950 's.

The propensity to migrate has been established as greatest among young people of working age. The major part of the migration has been of those less than 35 years of age. Women in particular have been abundantly represented among the migrants. As the migration movement among the rural population picks out the young people of working age, and frequently the female part of the population, the population structure of the rural areas is changed in an unfavourable direction. The population is aged, and a deficit of women arises.

\section{Emigration}

Although during the 1960's internal migration remained about constant, emigration increased. It has by no means been an easy matter to determine the extent of emigration. It has been impracticable to do so with the aid of Finland's official statistics, but resort has been necessary to the statistics of the recipient countries. In the 1950's, the obligation to carry a passport was removed between the Nordic countries, and thus it has not been possible to check the figures for emigration to Sweden, which during the 1960 's and especially towards their end attained significant dimensions. It was not until October 1969 that an agreement came into force: this was concerned with a joint Nordic booking of migration, which will enable future supervision of the migration of population between the Nordic countries.

For many years during the 1960's, the number of emigrants remained at less than 20000 people. Only during the years $1964-65$, and after 1968 , did the number of those who had moved away exceed this figure (Table 9).

The emigration to Sweden represented the greater part of such movement during the 1960 's. During the years $1961-65,74$ per cent, and during the years 1966-69, 83 per cent of all emigrants moved to Sweden (Committee report 1970: B 112, p. 14). Emigration to Sweden has become an important 
Table 9. Emigration during the 1960's.

\begin{tabular}{|c|c|c|c|c|c|}
\hline \multirow[t]{2}{*}{ Year } & \multirow[t]{2}{*}{ Emigrants } & \multirow{2}{*}{ Immigrants } & \multicolumn{2}{|c|}{ Net migration } & \multirow{2}{*}{$\begin{array}{l}\text { Migration } \\
\text { to Sweden }\end{array}$} \\
\hline & & & Number & Per 1000 & \\
\hline 1960 & 14000 & & & & 9100 \\
\hline 1961 & 14000 & 5000 & 9000 & 2.0 & 9100 \\
\hline 1962 & 12000 & 5500 & 6500 & 1.5 & 6500 \\
\hline 1963 & 12000 & 5000 & 7000 & 1.5 & 6300 \\
\hline 1964 & 22000 & 6000 & 16000 & 3.5 & 15400 \\
\hline 1965 & 25000 & 6500 & 18500 & 4.0 & 17300 \\
\hline 1966 & 19000 & 8000 & 11000 & 2.5 & 10100 \\
\hline 1967 & 14000 & 7500 & 6500 & 1.5 & 4400 \\
\hline 1968 & 21000 & 8000 & 13000 & 3.0 & 11000 \\
\hline 1969 & 47000 & 9000 & 38000 & 8.0 & 32600 \\
\hline
\end{tabular}

Source: Committee report 1970: B 112. p. 17.

factor in the development of Finland's population. This became extremely obvious in 1969, when the number of inhabitants of Finland declined for the first time since the 1860 's, even though the natural increase still amounted to more than 20000 people.

Moreover, emigration by women has become commoner than that by men. Nevertheless, the male number and proportion of emigrants were somewhat greater at the end of the decade than the corresponding figures in regard to women: in particular in respect of return migration, men were in the majority.

The greater part of the emigrants were unmarried, and were more than 15 years of age. As on migration they were often on the threshold of marriageable age, the frequency of marriage among them was high. However, this has not resulted in any greater fertility than in Finland. One contributory factor here, presumably, is that the fertility of emigrants represents an effort to maintain the same level as that of the place of migration. Economic factors, such as the acquisition of work and somewhere to live, along with fresh norms, have a diminishing effect upon fertility.

\section{Summary}

The significance of the 1960's to the development of population in Finland is noteworthy. By the end of the decade, the population of the country had diminished for the first time since the years of want during the 1860's.

However, the reason for this was not increased mortality, but must be sought in diminished fertility and increased emigration. The fertility, that declined throughout the whole of the 1960 's, was lowest during the closing years of the decade. Nonetheless, this would not as yet have resulted in 
diminution in the population of the country, as the natural increase exceeded 20000 persons, if emigration had not assumed considerable proportions in 1969. At that time, approximately 46000 people emigrated from Finland to other countries. The major part of the emigration was to Sweden, and although return migration occurred, the net emigration came to nearly 33000 persons.

The population of Finland did not only occur numerically, but structurally as well. Urbanisation and centralisation continued, and by the end of the 1960 's the population had for the first time become greater in the towns and townships than in the rural areas. The disproportion between the different parts of the country increased continuously. From remote tracts, and in particular from the eastern and northern parts of the country, people moved to the south, and in particular to Uusimaa. The population in rural areas diminished, their age increased, and the male surplus continued, when the young people in their best working years, including among them many women, moved to the residential areas. The disproportion in sex structure did not as yet during the sixties exercise an influence on the marriage rates, but if development continues it is probable that its effects will become apparent, and indirectly influence fertility.

\section{References}

Majava, Altti: Väestönmuutokset talousalueittain ja kunnittain vuosina $1951-1966$. Valtakunnansuunnittelutoimiston julkaisuja A: 21. Helsinki 1968.

Modeen, Gunnar: Suomen väkiluvun vastainen kehitys. Tilastokatsauksia 1934, 10. Helsinki 1934.

Piepponen, Paavo: Ikä ja avioliitto. Väestöpoliittisen Tutkimuslaitoksen julkaisuja. Sarja B 13. Helsinki 1968.

Salovaara, Leo: Aktiivinen työvoimapolitiikka. Helsinki 1970.

Siirtolaisuustutkimusten ohjelmointitoimikunnan mietintö. Komiteanmietintö 1970: B 112. Helsinki 1970 .

Bulletin of Statistics 1964, 12, 1967, 1, 1970, 11 ja 1971, 5.

Vital Statistics $1960-68$, SVT VI A: $119-130$.

General census of population 1960, II. SVT VI C: 103. Helsinki 1963. 